UDK 582.475:581.4(497.6 Olovo)

\title{
VARIABILITY OF SOME MORPHOLOGICAL FEATURES OF SILVER FIR (Abies alba Mill.) IN A NATIONAL TEST OF PROVENIENCES ${ }^{1}$

\author{
Varijabilnost nekih morfoloških svojstava obične jele (Abies alba Mill.) u \\ nacionalnom pokusu provenijencija ${ }^{1}$
}

\author{
Velid Halilović $^{2}$, Faruk Mekić ${ }^{2}$, Ćemal Višnjić ${ }^{2}$ Dalibor Ballian ${ }^{2}$
}

\begin{abstract}
The research has been carried out in a formal experiment with silver fir near Očevje-Olovo, with nine provenances originating from natural $\mathrm{BiH}$ population of 22 years of age. The research observed following provenances: communities from the area of Bugojno, Bosanski Petrovac, Olovo-Palež, Olovo-Klis, Pale, Konjic, Fojnica, Sokolac, and Prozor.

The analysis of diameter on the root collar found that there are statistically significant differences among the provenances. It was also found that the biggest diameter on the root collar was on the provenances of Fojnica, with $75.6 \mathrm{~mm}$, whereas the smallest was on the provenances of Olovo-Klis, with $65.2 \mathrm{~mm}$. In terms of breast height diameter, some statistically significant differences were also found, so that the biggest diameter was on the provenance of Fojnica, with $47.0 \mathrm{~mm}$, whereas the smallest value of this feature was on the provenance of Pale, with $41.6 \mathrm{~mm}$.

The analysis of the height of different provenances for the testing period, $1999-2005$ (7 years), suggested statistically significant differences among the provenances. The biggest value was on the provenance of Bosanski Petrovac, with $407 \mathrm{~cm}$, whereas the smallest height was on the provenance of Olovo-Klis, with $364 \mathrm{~cm}$.

The results obtained during this research provide valuable information, which can be used as indicators for successful differentiation of silver fir.
\end{abstract}

Key words: silver fir (Abies alba Mill.), provenance, variability, height, diameter.

\footnotetext{
${ }^{1}$ This paper, as a summary, was published in IUFRO (31 August - 4 September 2009), Hittisau (Bregenzerwald), Austria.

${ }^{2}$ Faculty of Forestry University of Sarajevo
} 


\section{INTRODUCTION - Uvod}

Silver fir (Abies alba Mill.) is one of the most important species of forest trees in view of the economy and environment in Bosnia and Herzegovina (BALLIAN AND ČABARAVDIĆ, 2005). The principal area populated by silver fir in Bosnia and Herzegovina is the central part of Dinnarides (FUKAREK 1970). The total space of high forests, with silver fir, mainly in mixed forests with beech and spruces, amounts to 562,237 ha or approximately $50 \%$ of all high forests in Bosnia and Herzegovina. The total mass of silver fir timber stock in all types of forests is $63,923,000 \mathrm{~m}^{3}$, which is around $23 \%$ of the total timber stock within all high forests, so that silver fir timber has also such a share in wood processing industry (UsčUPLIĆ 1992).

In $\mathrm{BiH}$ forests, silver fir represents one of the most important forest species, particularly because it is an extremely important stabilizer of forest ecosystems. That is the reason why it attracted such a large attention of a wide circle of European scientists. Discussing about the silver fir, it also has to be mentioned that it very sensitive species, which has been vulnerable for centuries in the Central European forests (ELLING, 1993; ELLING ET AL. 1999; WENTZEL 1980), due to the altered living conditions, and also often poor economic management with the forest, which contradicts the basic economic principles of rationalization and reduction of costs during the exploitation. However, in early 50's professionals began, initially at a slower pace and then more intensively, to work on securing and advancing the environmental conditions in the habitats of silver fir, aimed at formulation of more stable forest ecosystems, being the way to revive existing forest communities, in which silver fir grows and develops (PINTARIĆ 2002).

Despite all the efforts aimed at improvement of conditions for silver fir, its health status in Bosnia and Herzegovina during the last 40 years has had a tendency of constant deterioration (USČUPLIĆ ET AL. 2007). Unlike the fir forests in the neighboring Croatia, where fir deteriorates due to the damaging effects of pollution coming from air and soil (TIKVIĆ ET AL. 1995), the situation in BiH deteriorates due to the poor economic management (BALLIAN 2003). Week and unstable system of economic management results in destruction of structural stability of fir forests, which affects micro-ecological conditions in the forest, that is, community, including the renewal of this valuable species. Yet, destruction of the structure results directly in the appearance of parasites such as mistletoe (Viscum album var. abietis Beck.), leading to a subsequent appearance of other pathogens, dangerous for silver fir (UsčUPLIĆ 1992).

\section{OBJECTIVES - Objekat}

Objective of the research is to apply verified methods and identify differences between researched provenances, and show the productive possibilities for each of nine observed provenances through the analysis of tree height and thickness for those eco conditions. 


\section{MATERIAL AND METHOD - Materijal i metod}

Experimental plot of silver fir, intended for the research, was established in 1991 in the greater Olovo, the area of Delimus - section 86, management unit Krivaja, which makes a part of Forest management Olovsko. Altitude is $970 \mathrm{~m}$, while the exposition of the terrain is northern and is very suitable for the growth of silver fir, which is a dominant species in the neighboring forests. The terrain itself goes along the interval $10-20^{\circ}$, which is rather favorable considering the local orography of the terrain.

Table 1. Basic features of silver fir provenances used in this experiment

Tabela 1. Osnovne karakteristike provenijencija obične jele zastupljene u eksperimentu

\begin{tabular}{|l|c|c|c|c|}
\hline \multicolumn{1}{|c|}{ Provenance } & $\begin{array}{c}\text { Altitude } \\
(\mathbf{m})\end{array}$ & Exposition & Angle (\%) & $\begin{array}{c}\text { Position } \\
\text { Latitude / Longitude }\end{array}$ \\
\hline 1. Bugojno & 1.090 & $\mathrm{~N}-\mathrm{W}$ & $10-25$ & $43^{\circ} 59^{\prime} 29^{\prime \prime} / 17^{\circ} 22^{\prime} 27^{\prime \prime}$ \\
\hline 2. Bos. Petrovac & 900 & $\mathrm{~N}$ & 2 & $44^{\circ} 29^{\prime} 16^{\prime \prime} / 16^{\circ} 27^{\prime} 21^{\prime \prime}$ \\
\hline 3. Olovo-Palež & 960 & $\mathrm{~N}-\mathrm{E}$ & 12 & $44^{\circ} 03^{\prime} 04^{\prime \prime} / 18^{\circ} 37^{\prime} 07^{\prime \prime}$ \\
\hline 4. Pale & 1.200 & $\mathrm{~N}-\mathrm{E}$ & 20 & $43^{\circ} 48^{\prime} 02^{\prime \prime} / 18^{\circ} 32^{\prime} 51^{\prime \prime}$ \\
\hline 5. Konjic & 1.030 & $\mathrm{E}-\mathrm{EN}$ & $10-22$ & $43^{\circ} 32^{\prime} 22^{\prime \prime} / 18^{\circ} 01^{\prime} 06^{\prime \prime}$ \\
\hline 6. Fojnica & 1.010 & $\mathrm{~N}$ & $10-15$ & $43^{\circ} 55^{\prime} 57^{\prime \prime} / 17^{\circ} 53^{\prime} 48^{\prime \prime}$ \\
\hline 7. Sokolac & 940 & $\mathrm{~S}-\mathrm{W}$ & 13 & $43^{\circ} 53^{\prime} 42^{\prime \prime} / 18^{\circ} 42^{\prime} 17^{\prime \prime}$ \\
\hline 8. Olovo-Klis & 850 & $\mathrm{~N}-\mathrm{W}$ & 13 & $44^{\circ} 08^{\prime} 12^{\prime \prime} / 18^{\circ} 42^{\prime} 27^{\prime \prime}$ \\
\hline 9. Prozor & 1.300 & $\mathrm{~N}-\mathrm{E}$ & $5-10$ & $43^{\circ} 40^{\prime} 39^{\prime \prime} / 17^{\circ} 37^{\prime} 31^{\prime \prime}$ \\
\hline
\end{tabular}

Size of the plot in which the planting was carried out is $173 \mathrm{~m} \times 88 \mathrm{~m}$, that is, $1,522 \mathrm{ha}$, repeated five times, with two rows of plants serving as a protection to avoid the edging effect. Planting of provenances was carried out based on random block system (picture 1).

Planting material (as educated 3+2) was produced in seedbed in Zavidovići, and in spring 1991 it was planted in the field. In the area of Delimusa, earlier prepared for planting, the classic planting to the holes was carried out.

Planting material of silver fir, we used in this experiment, originates from the area of Bugojno, Bosanski Petrovac, Olovo-Palež, Pale, Konjic, Fojnica, Sokolac, Olovo-Klis, and Prozor, that is, in total from 9 natural populations at the altitude of 850 to $1.300 \mathrm{~m}$ (table 1 , picture 1 ).

Every plot is of dimension $14 \times 14 \mathrm{~m}$, in repetition, and planting of trees was carried out at distance of $2 \times 2 \mathrm{~m}$, while the distance between plots was $3 \mathrm{~m}$. Provenance in the plot was represented by 15 families and control group (picture 2). Every family and control group in the plot were represented with 4 trees, so that each of the families was represented with 20 trees, including the control group consisting of trees from each of the family. 


\begin{tabular}{|c|c|c|c|c|c|c|c|c|c|}
\hline Bugojno & $\begin{array}{c}\text { Olovo- } \\
\text { Klis }\end{array}$ & $\begin{array}{c}\text { Olovo- } \\
\text { Palež }\end{array}$ & Fojnica & Prozor & $\begin{array}{c}\text { Bosanski } \\
\text { Petrovac }\end{array}$ & Sokolac & Pale & Konjic & Control \\
\hline $\begin{array}{c}\text { Bosanski } \\
\text { Petrovac }\end{array}$ & Sokolac & Pale & Konjic & Control & Bugojno & $\begin{array}{c}\text { Olovo- } \\
\text { Klis }\end{array}$ & $\begin{array}{c}\text { Olovo- } \\
\text { Palež }\end{array}$ & Fojnica & Prozor \\
\hline Control & Bugojno & $\begin{array}{c}\text { Olovo- } \\
\text { Klis }\end{array}$ & $\begin{array}{c}\text { Olovo- } \\
\text { Palež }\end{array}$ & Fojnica & Prozor & Konjic & Sokolac & Pale & $\begin{array}{c}\text { Bosanski } \\
\text { Petrovac }\end{array}$ \\
\hline Fojnica & Prozor & $\begin{array}{c}\text { Bosanski } \\
\text { Petrovac }\end{array}$ & Sokolac & Konjic & Pale & Control & Bugojno & $\begin{array}{c}\text { Olovo- } \\
\text { Klis }\end{array}$ & $\begin{array}{c}\text { Olovo- } \\
\text { Palež }\end{array}$ \\
\hline Pale & Konjic & Control & Bugojno & $\begin{array}{c}\text { Olovo- } \\
\text { Klis }\end{array}$ & $\begin{array}{c}\text { Olovo- } \\
\text { Palež }\end{array}$ & Fojnica & $\begin{array}{c}\text { Bosanski } \\
\text { Petrovac }\end{array}$ & Prozor & Sokolac \\
\hline
\end{tabular}

Picture 1. Scheme of experimental plot and schedule of provenance in the area of "Delimusa" Slika 1. Shematski prikaz eksperimentalne plohe i raspored provenijencija na lokaciji „Delimusa“

Field research was carried out in autumn 2005, when the plants were about 20 years. Following elements were measures on the trees: diameter at breast height and the root collar and the entire height. The standard analysis of variant was used for the analysis of features, and Post Hoc and Duncan test for verification of obtained statistical differences, having applied the statistical program Statistica.

\section{RESULTS AND DISCUSSION - Rezultati i diskusija}

\section{Height of trees - Visina stabala}

Analysis of the tree height of silver fir was carried out during the last seven years. Analysis of data for the observation period 1999-2005 did not suggest major changes, that is, almost all provenances maintained same values of trend, as shown in table 2. Research of provenances for all these years suggested statistically significant difference, and the verification and grouping according to Duncan test suggested that provenances grouped in two homogenous groups. In addition to grouping in any group, one provenance usually remains as particular, whether by large or small value, which deviates from the group.

During the 7-years observed period, measuring of total heights established that the shortest height was on the provenance of Olovo-Klis $(364 \mathrm{~cm})$ and of Pale $(370$ $\mathrm{cm})$. The biggest values were noted on the provenance of Bosanski Petrovac, as shown in table 2.

Based on results of this research, it is obvious that the provenance of Bosanski Petrovac with its height deviates from other provenances, and/or, there is statistically significant difference between total heights of this provenance and total heights of provenances of Olovo-Klis and Pale. This feature in terms of other provenances suggests the grouping in the middle, and they are in the interval without clear significant differences. 
Table 2. Analysis of height of trees in years 1999 and 2005

Tabela 2. Analiza visina stabala u 1999. i 2005. godini

\begin{tabular}{|c|c|c|c|c|c|c|c|c|}
\hline \multirow{3}{*}{ No. } & \multirow{3}{*}{ Provenance } & \multicolumn{7}{|c|}{ Mean value \pm standard deviation } \\
\hline & & 1999 & $\begin{array}{c}\text { Duncan } \\
\text { test }\end{array}$ & $\mathrm{CV} \%$ & Provenance & 2005 & $\begin{array}{c}\text { Duncan } \\
\text { test }\end{array}$ & $\mathrm{CV} \%$ \\
\hline & & \multicolumn{7}{|c|}{$\mathrm{Cm}$} \\
\hline 1. & Olovo-Klis & $155 \pm 50,065$ & & 32 & Olovo-Klis & $364 \pm 106,343$ & & 29 \\
\hline 2. & Pale & $157 \pm 56,044$ & & 36 & Pale & $370 \pm 117,335$ & & 32 \\
\hline 3. & Olovo-Palež & $163 \pm 49,399$ & & 30 & Olovo-Palež & $376 \pm 120,795$ & & 32 \\
\hline 4. & Sokolac & $164 \pm 49,491$ & & 30 & Konjic & $383 \pm 126,224$ & & 28 \\
\hline 5. & Bugojno & $167 \pm 54,911$ & & 33 & Bugojno & $387 \pm 110,482$ & & 29 \\
\hline 6. & Fojnica & $167 \pm 53,157$ & & 32 & Prozor & $387 \pm 118,589$ & & 30 \\
\hline 7. & Prozor & $168 \pm 50,706$ & & 30 & Sokolac & $388 \pm 108,767$ & & 32 \\
\hline 8. & Konjic & $168 \pm 51,601$ & & 31 & Fojnica & $399 \pm 116,217$ & & 30 \\
\hline \multirow[t]{3}{*}{9.} & Bos.Petrovac & $171 \pm 56,157$ & & 33 & Bos.Petrovac & $407 \pm 127,456$ & & 31 \\
\hline & Average & $165 \pm 52,392$ & & 32 & Average & $385 \pm 116,912$ & & 30 \\
\hline & $\mathrm{F}$ - value & $2,55^{* *}$ & & & F - value & $3,24 * * *$ & & \\
\hline
\end{tabular}

The results obtained by MEKIĆ (1991) suggest that the provenances of Fojnica and Prozor had the smallest height in 1990, and the biggest Olovo-Palež and Bugojno. Following 15 years of growth, the provenances began taking over each other, and Bosanski Petrovac and Fojnica lead in height, while provenances of Olovo-Klis was the last. The grouping and deployment of provenances after two measurements, 1990 and 2005 , may be seen on the picture 2 .

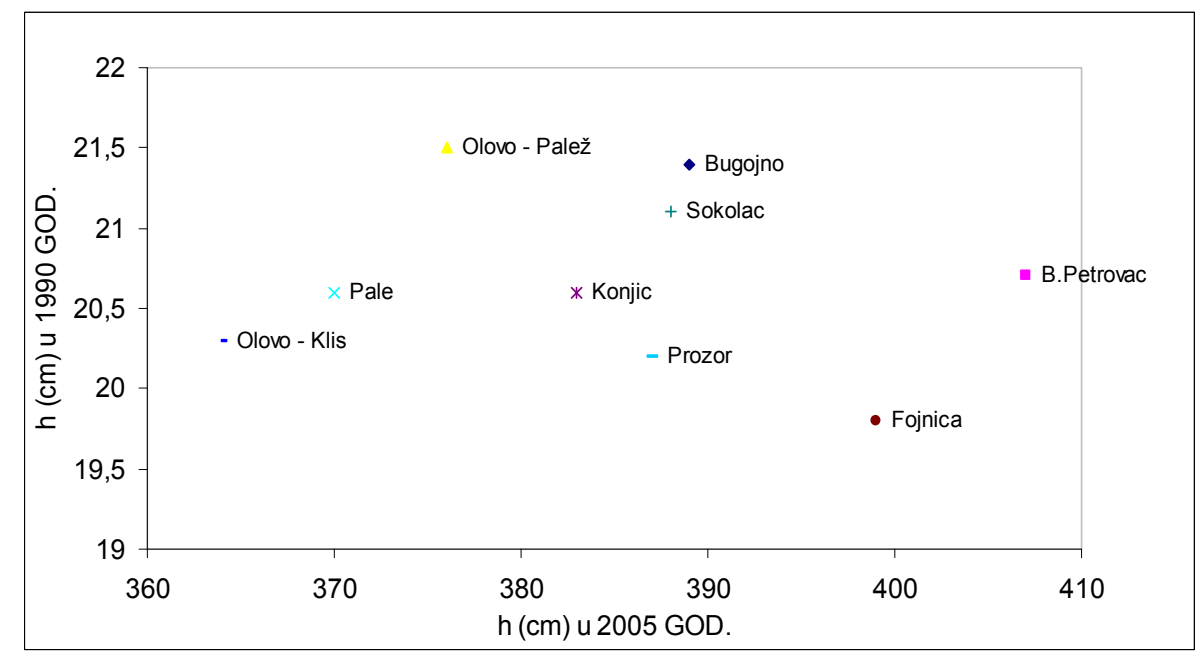

Picture 2. Comparison of average height of provenances in 1990 and 2005

Slika 2. Poređenje prosječnih visina stabala provenijencija u 1990. i 2005. godini 


\section{Diameter of trees - Prečnik stabala}

\section{Diameter on the root collar-Promjer na vratu korijena}

The table 3 shows that the biggest value of mean diameter on the root collar was on the provenance from the area of Fojnica $(75.6 \mathrm{~mm})$, and the smallest one was on the provenance of Olovo-Klis $(65.2 \mathrm{~mm})$. The analysis of variance suggested statistically significant difference, where $\mathrm{F}$ value had 6.22 (table 6.), which was confirmed by Duncan test that showed that the provenances grouped in two homogenous groups. In this way, we found out that along with the highest level of significance, the provenance of Fojnica stood out with the maximal diameter on the root collar. With its mean value, it significantly deviates from other provenances in the group one. As for the second group, including the provenance of Fojnica as well, there are statistically significant deviation as compared to the provenances of Olovo-Klis, Olovo-Palež, and Pale, which showed the smallest value of mean diameter on the root collar, and are outside the group.

Table 3. Analysis of diameter on the root collar

Tabela 3. Analiza prečnika na vratu korijena

\begin{tabular}{|c|c|c|c|c|}
\hline \multirow{3}{*}{ No. } & \multirow{3}{*}{ Provenance } & \multicolumn{3}{|c|}{ Average \pm standard deviation } \\
\hline & & D $0,05 \mathrm{~m}$ & Duncan-test & $\mathrm{CV} \%$ \\
\hline & & \multicolumn{3}{|c|}{$\mathrm{Mm}$} \\
\hline 1. & Olovo-Klis & $65,2 \pm 21,819$ & & 33 \\
\hline 2. & Olovo-Palež & $65,8 \pm 22,853$ & & 35 \\
\hline 3. & Pale & $66,3 \pm 20,939$ & & 32 \\
\hline 4. & Konjic & $68,7 \pm 22,252$ & & 32 \\
\hline 5. & Bugojno & $71,4 \pm 25,668$ & & 35 \\
\hline 6. & Prozor & $71,6 \pm 23,266$ & & 32 \\
\hline 7. & Sokolac & $72,1 \pm 21,640$ & & 30 \\
\hline 8. & Bos.Petrovac & $72,4 \pm 23,893$ & & 33 \\
\hline 9. & Fojnica & $75,6 \pm 24,501$ & & 32 \\
\hline \multicolumn{2}{|r|}{ Average } & $69,9 \pm 22,98$ & & \\
\hline \multicolumn{2}{|r|}{$\mathrm{F}$ - value } & $6,22 * * *$ & & 33 \\
\hline
\end{tabular}

\section{Breast height diameter - Prsni promjer}

The biggest value of the mean breast height diameter was on the provenance of Fojnica with $47.0 \mathrm{~mm}$, while the smallest had the provenance of Pale with $41.6 \mathrm{~mm}$ (table 4).

The analysis of variance suggested statistically significant differences with $\mathrm{F}$ value 2.91 (table 4 ). 
Table 4. Analysis of the breast height diameter

Tabela 4. Analiza prsnog prečnika

\begin{tabular}{|c|c|c|c|c|}
\hline \multirow{3}{*}{ No. } & \multirow{3}{*}{ Provenance } & \multicolumn{3}{|c|}{ Average \pm standard deviation } \\
\hline & & D $1,30 \mathrm{~m}$ & Duncan-test & $\mathrm{CV} \%$ \\
\hline & & \multicolumn{3}{|c|}{$\mathrm{Mm}$} \\
\hline 1. & Pale & $41,6 \pm 16,608$ & & 40 \\
\hline 2. & Olovo-Klis & $41,7 \pm 16,220$ & & 39 \\
\hline 3. & Olovo-Palež & $42,5 \pm 16,643$ & & 39 \\
\hline 4. & Prozor & $44,1 \pm 16,911$ & & 38 \\
\hline 5. & Bugojno & $44,5 \pm 19,153$ & & 43 \\
\hline 6. & Sokolac & $44,7 \pm 17,181$ & & 38 \\
\hline 7. & Konjic & $45,0 \pm 16,314$ & & 36 \\
\hline 8. & Bos. Petrovac & $46,3 \pm 19,061$ & & 41 \\
\hline \multirow[t]{3}{*}{9.} & Fojnica & $47,0 \pm 18,477$ & & 39 \\
\hline & Average & $44,2 \pm 17,39$ & & 39 \\
\hline & $F$-value & $2,91 * *$ & & \\
\hline
\end{tabular}

This was confirmed by Duncan test that proved that the provenances grouped in two homogenous groups, as was the case with diameter of the root collar. In this way, we found out that the provenance of Fojnica stood out with the highest level of significance with its biggest breast height diameter. With its mean value, it significantly deviates from other provenances in the first group. As for the second group, involving the provenance of Fojnica, there is a statistically significant deviation from the provenances of Olovo-Klis, Olovo-Palež, and Pale that showed the smallest value of mean diameter on the root collar, and are outside the group.

These results are very interesting when compared with those obtained by MEKIĆ (1991) in his research on the same provenances. So he, during the analysis of the seeding material of age $2+0$ and $2+3$, got the statistically significant differences for the height of trees in 1988 and 1990, that is, in the second and the fifth year following the planting and re-planting of thee trees in the seedbed. After fifteen years from the beginning of experiment, this research registered again the differences among the provenances in terms of height and diameter, as can be seen in tables 2-4.

Results of research on many experiments on provenances started during the mid and late $20^{\text {th }}$ century dismiss the assumption related to weak variability of silver fir, which applied for so many years, from ENGLER (1905) to mid 50's of the last century, and in some cases even up to 80's. It was then proved in a series of researches that even the silver fir has variability that does not fall behind the variability of other coniferous and deciduous species, analyzed by many researchers: VINŠ (1966), LAFFERS (1975), KRAMER 1979, 1980, KRAL 1980, KoRPEL' AT AL. 1981, and in Bosnia and Herzegovina by BALLIAN (2000), based on field experiments.

This research analyzed the material from a smaller part of natural community of fir in Bosnia and Herzegovina, and a smaller variability than registered was 
expected, especially since the research was carried out in an early stage, where the inheritance features have not been sufficiently expressed. Based on the results obtained, that is, the registered significant differences, we have to refer here to the specificities of the Dinnarides, where there are huge differences in environment in a small space that directly affect variability and differentiation of the silver fir population (BALLIAN 2003).

These results were also confirmed by the research on same provenances by RATKNIĆ ET AL. (2002) for the experimental space Pljevlje, and the latest confirmation came from this research too. We were not able to make here some global recommendations as only the local provenances were analyzed, and these results apply only to conditions in Bosnia and Herzegovina, though we also have to be careful here not to globalize results. Some more valuable conclusions would need comparative experimental spaces, with same provenances included in the research; in other words, a broader research should involve the international level.

The obtained results confirm the opinion of ample researchers who believe that species of forest trees in Dinnarides suggest a huge variability compared to the same species in the north, and a huge variability may be found in a relatively small space (BALLIAN 2005), which we managed to confirm by this research and the analysis of height too.

\section{CONCLUSION - Zaključak}

For this researched feature of height and diameter, the statistically significant difference was found among nine provenances of silver fir in the experiment Delimusa in the area of Olovo.

The provenance of Bosanski Petrovac had the biggest height and it varied between $171 \mathrm{~cm}$ in 1999 (14 years) and $407 \mathrm{~cm}$ in 2005 (20 years).

The smallest height value had the provenance of Olovo-Klis. Value varied from 155 $\mathrm{cm}$ in 1999 and $364 \mathrm{~cm}$ in 2005.

As for the diameters, measurements were carried out in spring 2005 when the plants were 19 years old. The biggest value on the neck collar had provenance of Fojnica, $75.6 \mathrm{~mm}$, and the smallest provenance of Olovo-Klis, $65.2 \mathrm{~mm}$.

The smallest value of the diameter at breast height had provenance of Pale, $41.6 \mathrm{~mm}$, and the biggest provenance of Fojnica, $47.0 \mathrm{~mm}$. It may be stated that in this case that the smallest values of diameter at breast height reoccur on the provenance of Olovo-Klis, whose value was $41.7 \mathrm{~mm}$, and it followed the provenance of Pale.

Based on results, it may be concluded that there are differences among the populations from different environments, that is, probable differences in the features of the provenance stands influence morphological differentiation among the populations. 
This research confirmed that silver fir from central Dinnarides, in terms of analyzed features of height and diameter, suggest a high degree of variability, although it was carried out in a relatively small area.

As all the researched features suggest statistically significant differences, they could serve, at certain age of the material, for experiments to assess the interpopulation variability in new research.

\section{Reference - Literatura}

BALLIAN, D. (1999): Unutarpopulacijska i međupopulacijska varijabilnost morfoloških i fizioloških svojstava obične jele (Abies alba Mill.) u jednom dijelu prirodnog rasprostiranja u Bosni i Hercegovini, Annales forestales, Vol. 24, Br. 1, str. 1-23, Zagreb.

BALLIAN, D. (2000): Analiza rasta klijanaca obične jele ( Abies alba Mill.) različitih populacija putem half-sib potomstva, Šumarski list br. 11-12: 649-660, Zagreb.

BALliAN, D. (2003): Procjena genetičke varijabilnosti obične jele (Abies alba Mill.) analizom izoenzima u dijelu prirodnih populacija Bosne i Hercegovine i Hrvatske, Šumarski list br. 3-4: 135-151, Zagreb.

BALLIAN, D., ČABARAVDIĆ, A. 2005: Međupopulacijska varijabilnost nekih morfoloških svojstava obične jele (Abies alba Mill.) iz središnje Bosne. Radovi Šumarskog instituta 40 (1): 5-18, Jastrebarsko.

Dizdarević, H., Prolić, N., Mekić, F., Mikić, T., Vučetić, M., Pintarić, K., Luteršek, D., GaVRilović, D., Uščuplić, M., LaZareV, V., Vukorep, I., Stefanović, V., MILOSLAVIĆ, L., VRLJIČAK, J. (1987): Revizija postojećih i izbor novih sjemenskih sastojina na području SR BiH. Rukopis. Sarajevo. str. 452.

ELLING, W. (1993): Immission im Ursachenkomplex von Tannenschääund Tannensterben. Algemeine Forst-Zeitschrift 48: 87-95.

ELLING, W., BRETSCHNEIDER, M., SCHWARZFISCHER, C. (1999): Zuwachsdepression an Tanne durch Schwefel-Emissionen. Algemeine Forst-Zeitschrift 54: 896-898.

FUKAREK, P. (1970): Areali rasprostranjenosti bukve, jele i smrče na području Bosne i Hercegovine. Akademija nauka i umjetnosti BiH, radovi XXXIX, knjiga 11: 231 256.

KORPEL, Š., PAULE, L. (1981): Provenienčné výskamné plochy lesných drevín, etapa: jedla biela. VŠLD, Zvolen, str. 60.

KRAL, F. (1980): Waldgeschichtliche Grundlagen für die Ausscheidung von Ökotypen bei Abies alba. 3 IUFRO Tannensymposium: 158-168, Wien.

KRAMER, W. (1979): Zur Herkunftsfrage der Weißtanne (Abies alba Mill.), Forstarchiv, 50 (7-8): str.153-160.

KRAMER, W. (1980): Osteuropäische Herkünften von Weißtanne (Abies alba Mill.) 
Forstarchiv, 51 (9): str.165-169.

LAFFERS, A. (1975): Výsledky hodnotenia sadencov proveniencií jedle zo Sl'ovenska. Ved. Pr. výsk. Úst. Lesn. Hosp. Zvolen, 20: str. 195-223.

MEKIĆ, F. (1991): Morfološke karakteristike petogodišnjih sadnica jele (Abies alba Mill.) sa devet lokaliteta u BiH. Univerzitet u Beogradu, Glasnik Šumarskog fakulteta, Beograd br. 73. str. $141-152$.

PINTARIĆ, K. (2002): Šumsko-uzgojna svojstva i život važnijih vrsta šumskog drveća. Sarajevo: Udruženje šumarskih inžinjera i tehničara Federacije Bosne i Hercegovine. str. 221.

RATKNIĆ, K., VuČKović, M., STAmenković, V., STAJIĆ, B. (2002): Silver fir (Abies alba Mill) provenance test in southwestern Serbia u sklopu 10. Internationalen IUFROTannen-symposium am 16. - 20. Sept. 2002 an der FAWF in Trippstadt, 59-67.

UsčUPLIĆ, M. (1992): Uticaj sistema gazdovanja na pojavu imele (Viscum album L.). Glasnik Šumarskog fakulteta u Beogradu, str. 7-18.

Usčuplić, M., Dautbašıć, M., Treštić, T., Selman, E., Mujezinović, O., Nišlć, T., JOKANOVIĆ, B. (2007): Bolesti i štetnici obične jele (Abies alba Mill.) u Bosni i Hercegovini. Društvo za zaštitu bilja u BiH. Sarajevo, str 115.

Vinš, B. (1966): Príspevek k výzkumu promenlivosti jedle (Abies alba Mill.). Rozpravy. CSAV, 76 (15): str. 1-82.

WENTZEL, K. F. (1980): Weißtanne = immissionsempfind-lichste heimische Baumart. Algemeine Forst-Zeitschrift 35: 373-374.

\section{Sažetak}

Obična jela (Abies alba Mill.) je najznačajnija i ekonomski najvažnija vrsta četinara u Bosni i Hercegovini. Zbog toga joj treba dati posebno mjesto u naučnim istraživanjima $\mathrm{s}$ ciljem povećanja njezinog učešća u šumskom fondu. U nizu postavljenih ogleda sa jelom diljem Bosne i Hercegovine izdvajamo jedan koji je trebao dati odgovor koja provenijencija najbolje odgovara Olovskom području.

Istraživanje je provedeno na formiranom ogledu sa jelom u neposrednoj blizini Očevje - Olovo, sa devet provenijencija porijeklom iz prirodnih populacija $\mathrm{BiH}$ u starsoti od 22 godine. U istraživanju su posmatrane sljedeće provenijencije: sastojine iz okoline Bugojna, Bos. Petrovca, Olovo - Paleža, Olovo - Klisa, Pala, Konjica, Fojnice, Sokoca i Prozora.

Cilj ovog istraživanja je da se savremenim statističkim metodama, uz primjenu multifaktorijalne analize, utvrdi međuprovenijencijska varijabilnost nekih morfoloških svojstava (promjer korjenovog vrata, prsnog promjera i visine stabala).

Analizom promjera na vratu korijena utvrđeno je da postoji statistički značajna razlika između provenijencija. Također je utvrđeno da je najveće promjere na vratu korijena imala provenijencija Fojnica sa $75,6 \mathrm{~mm}$, a najmanju vrijednost 
provenijencija Olovo - Klis sa $65,2 \mathrm{~mm}$. Kada je u pitanju promjer na prsnoj visini također su utvrđene statistički značajne razlike tako da je najveću vrijednost imala provenijencija Fojnica sa $47,0 \mathrm{~mm}$, dok je najmanju vrijednost ovog svojstva pokazuje provenijencija Pale sa $41,6 \mathrm{~mm}$.

Analizom visina, devet različitih provenijencija za ispitivani vremenski period od 1999 pa do 2005. godine (7 godina), dobili smo statistički značajne razlike između provenijencija. Najveće vrijednosti pokazala je provenijencija Bosanski Petrovac sa $407 \mathrm{~cm}$, a najmanju visinu imala je provenijencija Olovo - Klis sa $364 \mathrm{~cm}$.

Dobiveni rezultati iz ovog istraživanja daju vrijedne informacije koje se mogu upotrijebiti kao pokazatelj za uspješnu diferencijaciju obične jele, odnosno za procjenu međupopulacijske varijabilnosti kada su u pitanju pomenuti parametri, ali samo za ekološke uvjete koji su slični onim koji vladaju na istraživanoj površini. 